\title{
Clinical Study \\ Improving Outcomes After Relapse in Ewing's Sarcoma: Analysis of 114 Patients From a Single Institution
}

\author{
Anne M. McTiernan, Anna M. Cassoni, Deirdre Driver, Maria P. Michelagnoli, \\ Anne M. Kilby, and Jeremy S. Whelan \\ Department of Oncology, University College Hospital, 250 Euston Road, London NW1 2PG, UK \\ Received 16 August 2005; Revised 13 August 2006; Accepted 22 August 2006
}

\begin{abstract}
The outcome for patients with relapsed Ewing's sarcoma is poor. A retrospective analysis was carried out to identify factors associated with improved survival. Between 1992 and 2002, 114 patients presented with relapsed or progressive disease. Median time to progression/relapse was 13 months (range, 2-128). Treatment at relapse included high dose treatment (HDT) in 29 patients, and surgery or definitive radiotherapy in 29.2 and 5-year post relapse survival (PRS) was $23.5 \%$ and $15.2 \%$, respectively. In multivariate analysis, the most significant factors associated with improved survival were disease confined locally or to the lungs (2-year PRS, $40 \%$ versus $6 \% ; P<.001$ ), relapse $>18$ months from diagnosis $(2$-year PRS, 53\% versus $8 \%$; $P<.001)$, HDT at relapse (2-year PRS, $62 \%$ versus $11 \% ; P<.001$ ), and surgery and/or radiotherapy at relapse (2-year PRS, $51 \%$ versus $14 \% ; P<.001$ ). First treatment failure in Ewing's sarcoma is mostly fatal. Improved survival can be achieved in selective patients with aggressive treatment. These improvements are confined to those without bone or bone marrow metastases.
\end{abstract}

Copyright (c) 2006 Anne M. McTiernan et al. This is an open access article distributed under the Creative Commons Attribution License, which permits unrestricted use, distribution, and reproduction in any medium, provided the original work is properly cited.

\section{INTRODUCTION}

Though still biologically enigmatic, Ewing's sarcoma family of tumours (ESFT) has now been repeatedly demonstrated to be curable cancers. Results from large studies of firstline combined modality treatments indicate that perhaps two thirds of patients will be long-term survivors. However, for patients with relapsed or progressive disease, the prognosis is very poor, with only a small proportion of patients being cured [1-3]. In order to identify the factors that might be associated with improved survival in patients with relapsed or progressive ESFT, we carried out a retrospective analysis at our institution, together with a review of the literature.

\section{PATIENTS AND METHODS}

\section{Patients characteristics}

Between 1992 and 2002, 61 males and 53 females, median age 19 (range, 4-48), presented to the London Bone and Soft Tissue Sarcoma Service with relapsed or progressive ESFT. The patient characteristics are given in Table 1. Fiftythree patients had metastases at diagnosis, of whom 29 had metastases confined to the lungs. Primary site was of the extremities in 56 patients, pelvis in 30 patients, and central (nonpelvic) in 26. Two other patients had multifocal tumours. There were 87 primaries in bone and 27 soft-tissue tumours. The median tumour volume, assessed in $86 \mathrm{pa}-$ tients, was $255 \mathrm{~mL}$ (range, 50-3500 mL). Diagnosis had been established by morphology and immunocytochemistry in all patients, with no routinic use of molecular diagnostic techniques. Confirmation of recurrence by biopsy was undertaken whenever possible.

\section{First-line treatment}

Details of first-line chemotherapy are given in Table 1. The majority of patients $(90 \%)$ had been treated in accordance with successive European protocols for ESFT, with those diagnosed before 1993 being treated according to the ET-2 protocol [4]; those diagnosed between 1993 and 1997 being treated according to the Eicess' 92 protocol [5]; and patients diagnosed from 1998 onwards being treated with 6 cycles of vincristine, ifosfamide, doxorubicin, and etoposide, followed by consolidation treatment with either 8 cycles of vincristine, actinomycin, and ifosfamide or cyclophosphamide, or highdose therapy (HDT) with busulphan and melphalan [6], in accordance with the current EURO-EWING 99 protocol (ISRCTN:61438620). All but 3 patients received doxorubicin 
TABle 1: Patients characteristics. (Abbreviations: $V$ = vincristine; $D$ = doxorubicin I = ifosfamide, $\mathrm{E}=$ etoposide, $\mathrm{A}=$ actinomycin $-\mathrm{D}, \mathrm{C}$ = cyclophosphamide $\mathrm{HDT}=$ high-dose therapy; $\mathrm{PD}=$ progressive disease.)

\begin{tabular}{|c|c|}
\hline & No (\%) \\
\hline Median age at diagnosis: & 19 years (range $4-48$ ) \\
\hline Male & $61(53.5)$ \\
\hline Female & $53(46.5)$ \\
\hline \multicolumn{2}{|l|}{ Site of primary: } \\
\hline Extremity & $56(49.2)$ \\
\hline \multicolumn{2}{|l|}{ Axial/Central } \\
\hline Pelvis & $30(26.3)$ \\
\hline Trunk & $22(19.4)$ \\
\hline Other $^{(a)}$ & $4(3.5)$ \\
\hline Multifocal & $2(1.8)$ \\
\hline \multicolumn{2}{|l|}{ Size of primary tumour: } \\
\hline$<100 \mathrm{~mL}$ & $73(64.0)$ \\
\hline$>100 \mathrm{~mL}$ & $13(11.4)$ \\
\hline Unknown & $28(24.6)$ \\
\hline \multicolumn{2}{|l|}{ Metastases at diagnosis: } \\
\hline None & $61(53.5)$ \\
\hline Lung only & $29(25.4)$ \\
\hline Bone \pm other, (excluding bone marrow) & $8(7.0)$ \\
\hline Bone marrow \pm other & $14(12.3)$ \\
\hline Lymph node & $2(1.8)$ \\
\hline \multicolumn{2}{|l|}{ First-line chemotherapy protocol: } \\
\hline ET-2 (VAID) & $17(14.9)$ \\
\hline Eicess' 92 (VAID $\pm \mathrm{E} \pm \mathrm{C}$ ) & $50(43.9)$ \\
\hline EE99 (EVAID $\pm \mathrm{C} \pm \mathrm{HDT})$ & $36(31.2)$ \\
\hline P6 (VDCIE) & $5(4.4)$ \\
\hline MMT'89 (VAI or VAC) & $3(2.6)$ \\
\hline VDC & $2(1.8)$ \\
\hline ID & $1(<1)$ \\
\hline \multicolumn{2}{|l|}{ Site of first relapse/PD: } \\
\hline Local & $29(25.4)$ \\
\hline \multicolumn{2}{|l|}{ Distant } \\
\hline Lung only & $32(28.1)$ \\
\hline Extrapulmonary & $33(28.9)$ \\
\hline \multicolumn{2}{|l|}{ Combined } \\
\hline Local + lung only & $8(7.0)$ \\
\hline Local + extrapulmonary & $12(10.5)$ \\
\hline
\end{tabular}

(a) Other: scalp $=1$, sphenoid $=1$, mandible $=1$, neck $=1$, multifocal $=2$.

and all but 4 patients received ifosfamide as part of first-line treatment. Fourteen patients received HDT as consolidation of first-line therapy.

\section{Local treatment}

Local treatment was surgery alone in 34 patients, surgery and adjuvant radiotherapy in 20 patients ( 2 patients with preoperative radiotherapy), and radiotherapy alone in 46 patients. Fourteen patients had no local treatment due to widespread bone metastases in 3 patients (all 3 received HDT as part of first-line treatment), disease progression in 8 patients, persistent bone marrow disease in 2, and patient refusal in the presence of widespread metastatic disease in 1 . One further patient underwent pulmonary metastatectomy for persistent pulmonary metastases at the end of first-line treatment.

\section{Statistical methods}

Survival after first treatment failure, termed postrelapse survival (PRS), was calculated from the date of PD or recurrence to the date of death or date of last followup. The duration of first event-free survival (EFS1) was calculated from the date of diagnosis to the date of first treatment failure. PRS was estimated using Kaplan-Meier methods [7]. The significance of influencing factors was tested by the log-rank test. In the case of more than two curves, the overall $P$ value was given. Factors considered included demographic factors (age at diagnosis, gender, and age at relapse), diagnostic factors (primary site, metastases at diagnosis, tumour volume), local treatment in first-line therapy, factors at relapse (timing of relapse and site of relapse), and treatment at relapse. Multivariate analysis was carried out using Cox's proportional hazards model [8], with all variables found to be significant in univariate analysis being entered into a multivariate model using a stepwise procedure.

\section{RESULTS}

\section{Details at relapse/progressive disease}

Thirty-seven patients developed PD within first-line treatment and 77 recurrent disease. The median time to first treatment failure was 13 months (range, 2-128 months) with $42 \%$ of events occurring within the first 12 months. Site of first relapse or progression is given in Table 1.

\section{Treatment of relapse}

\section{Chemotherapy}

Eighty-nine patients $(78 \%)$ were treated with chemotherapy at relapse, 12 with palliative intent only. Chemotherapy details at relapse are given in Table 2. Several different regimens were employed reflecting patient factors (major organ function, duration of remission, need for mobilisation, and collection of stem cells) and evolving practice. Patients were often treated with more than one regimen in an attempt to reduce disease burden to the minimum achievable one. The majority of patients were treated with secondline regimens, principally carboplatin-based chemotherapy [9]. When short durations of response with carboplatin regimens were observed, and in response to others' data, highdose ifosfamide, at a median dose of $15 \mathrm{~g} / \mathrm{m}^{2}$ (range $12 \mathrm{~g} / \mathrm{m}^{2}-$ $18 \mathrm{~g} / \mathrm{m}^{2}$ ), was employed [10]. Twenty-two patients, the majority of whom relapsed more than 6 months from the 
TABLE 2: Definitive treatment at relapse. (Abbreviations: RT $=$ radiotherapy; HDT = high-dose therapy; TBI = total body irradiation.)

\begin{tabular}{|c|c|}
\hline Treatment & No \\
\hline \multicolumn{2}{|l|}{ Chemotherapy $(n=89)$} \\
\hline - Carboplatin, etoposide, cyclophosphamide & 26 \\
\hline $\begin{array}{l}\text { - Ifosfamide, doxorubicin, }+/- \text { actinomycin, } \\
+/ \text { - vincristine, }+ \text { / - etoposide }\end{array}$ & 22 \\
\hline - High-dose ifosfamide $\left(12-18 \mathrm{~g} / \mathrm{m}^{2}\right)$ & 18 \\
\hline- Other $^{(\mathrm{a})}$ & 11 \\
\hline - Palliative only & 12 \\
\hline \multicolumn{2}{|l|}{ Surgery $(n=20)$} \\
\hline - Excision of local recurrence (no RT) & 11 \\
\hline - Excision of local recurrence + RT & 4 \\
\hline - Metastatectomy: Lung & 3 \\
\hline Cerebral & 1 \\
\hline Para-spinal mass & 1 \\
\hline \multicolumn{2}{|l|}{ Definitive radiotherapy $(n=8)$} \\
\hline - Local recurrence & 4 \\
\hline - Bone metastases & 4 \\
\hline \multicolumn{2}{|l|}{$\operatorname{HDT}(n=29)$} \\
\hline - Busulphan + melphalan & 19 \\
\hline - Melphalan + etoposide (+ TBI, 3 patients) & $7(3)$ \\
\hline - Melphalan (+ TBI, 1 patient $)$ & $2(1)$ \\
\hline - Busulphan + cyclophosphamide & 1 \\
\hline
\end{tabular}

(a) Other: ifosfamide + etoposide $=3$; cisplatin + etoposide \pm vincristine $=$ 3 ; vincristine + doxorubicin + cyclophosphamide $=3$; cyclophosphamide + topotecan $=1$; ifosfamide + vincristine $=1$.

end of first-line treatment, were initially retreated with an ifosfamide/doxorubicin-based regimen, to maximise exposure to anthracycline-based chemotherapy. Twenty-five patients were not treated with chemotherapy at relapse or progression, due to either poor tolerance in the presence of widespread refractory disease or rapid relapse after HDT, or patient choice.

\section{High dose therapy at relapse}

Twenty-nine of 77 patients $(38 \%)$ treated with curative intent at progression/relapse were treated with high-dose chemotherapy after second-line chemotherapy. Patients were treated with second-line treatment until remission was achieved or there was no further response. HDT comprised of busulphan and melphalan in 19 patients, and other regimens in 10. For those who proceeded to HDT at relapse, the median time from diagnosis to relapse was 23 months (range, 3-70 months). The best response at time of HDT was CR in 13 patients, $\mathrm{PR}$ in 8 , responding disease in 7 , and progressive disease in 1 patient. This latter patient had operable lung metastases at relapse and was therefore deemed suitable for HDT, despite disease progression. All other patients treated with curative intent were initially considered for HDT, but did not receive it principally due to inadequate response to second-line chemotherapy, rapid progression of initially responding disease, insufficient major organ function, or patient preference. The probability of a patient receiving HDT at relapse remained constant over the 10-year period $(P=.589)$.

\section{Surgery}

Twenty-one patients (18\%) had surgery as part of secondline treatment, although for one patient this was for palliative amputation of local recurrence only. Fifteen underwent excision of a local recurrence (4 with adjuvant radiotherapy), achieving second complete remission in 11 patients, and 4 with disease elsewhere, in anticipation of proceeding to HDT. Metastatectomies were performed in 5 patients, all with complete macroscopic excision. Three patients underwent lung metastatectomy (one with adjuvant whole lung irradiation), 1 patient had a cerebral metastatectomy, and 1 patient underwent excision of a para-spinal mass. In total, complete macroscopic resections were achieved in 16 of the 20 patients.

\section{Radiotherapy}

Sole definitive radiotherapy for relapse was given to 8 patients. In 4 patients this was for local recurrence deemed unresectable ( 3 extremity tumours, 1 chest wall). Three patients, 1 of whom also underwent HDT, received definitive radiotherapy to isolated bone metastases, and 1 patient with 2 sites of distant metastases received radiotherapy to both sites following TBI (given as part of HDT) to achieve a radical dosage to both sites of disease.

\section{Survival}

\section{Postrelapse survival}

At 1st April 2005, the median followup for the whole group was 67 months (range, 0-129). At this time 14 patients $(12.3 \%)$ remained alive continuously disease free, with a median followup of 61 months from first relapse (range, 35-129 months). Another patient was alive and disease free following resection of a further loco-regional recurrence 58 months after first relapse, and a second patient had become lost to followup with uncontrolled disease 19 months from relapse.

Three patients $(2.6 \%)$ died of causes related to further treatment. One died of pneumocystis carinii during chemotherapy for a second relapse having previously been treated with HDT; one patient died of gastrointestinal toxicity 3 months after HDT; and one patient suffered radiation pneumonitis with lung abscesses and chronic infection after HDT and lung irradiation, dying 18 months later. Recurrent disease was suspected but not proven to be present.

The median estimated PRS for the whole group was 9 months (range 0-129), with the 2- and 5-year estimated PRS being $23.5 \%( \pm 4.0 \%$, standard error $)$ and $15.2 \%( \pm 3.4 \%)$, respectively (Figure 1). 
TABLE 3: Summary of univariate analysis. (Abbreviations: $\mathrm{SE}=$ standard error; EFS1 = first event free survival; NR = not reached; RT = radiotherapy.)

\begin{tabular}{|c|c|c|c|c|c|}
\hline \multirow{2}{*}{ Variable } & \multirow{2}{*}{ Grouping } & \multirow{2}{*}{ No of patients } & \multicolumn{2}{|c|}{ \% Postrelapse survival ( $\pm 1 \mathrm{SE})$} & \multirow{2}{*}{$\begin{array}{c}P \text { value } \\
(\log \text { rank })\end{array}$} \\
\hline & & & 2-year & 5-year & \\
\hline All patients & - & 114 & $23.5( \pm 4.0)$ & $15.2( \pm 3.4)$ & - \\
\hline \multicolumn{6}{|l|}{ Demographics } \\
\hline Gender & $\begin{array}{c}\text { Male } \\
\text { Female }\end{array}$ & $\begin{array}{l}61 \\
53\end{array}$ & $\begin{array}{l}19.7( \pm 5.1) \\
28.0( \pm 6.2)\end{array}$ & $\begin{array}{l}14.8( \pm 4.6) \\
15.7( \pm 5.1)\end{array}$ & .9902 \\
\hline Age at diagnosis & $\begin{array}{l}\leq 19 \text { years } \\
\geq 20 \text { years }\end{array}$ & $\begin{array}{l}62 \\
52\end{array}$ & $\begin{array}{l}22.1( \pm 5.3) \\
25.0( \pm 6.0)\end{array}$ & $\begin{array}{l}15.1( \pm 4.7) \\
15.4( \pm 5.0)\end{array}$ & .8042 \\
\hline \multicolumn{6}{|l|}{ Disease at diagnosis } \\
\hline Primary site & $\begin{array}{c}\text { Extremity } \\
\text { Pelvis } \\
\text { Central } \\
\text { Multifocal }\end{array}$ & $\begin{array}{c}56 \\
30 \\
26 \\
2\end{array}$ & $\begin{array}{c}30.1( \pm 6.2) \\
20.0( \pm 7.3) \\
15.4( \pm 7.1) \\
0\end{array}$ & $\begin{aligned} & 20.4( \pm 5.5) \\
& 13.3( \pm 6.2) \\
& 7.7( \pm 5.2) \\
&-\end{aligned}$ & $.5163^{*}$ \\
\hline Metastases & $\begin{array}{c}\text { None } \\
\text { Lung } \\
\text { Extra-pulmonary }\end{array}$ & $\begin{array}{l}61 \\
29 \\
24\end{array}$ & $\begin{array}{c}32.4( \pm 6.0) \\
24.1( \pm 8.0) \\
0\end{array}$ & $\begin{array}{c}18.8( \pm 5.1) \\
20.1( \pm 7.6) \\
-\end{array}$ & $<.0001$ \\
\hline \multicolumn{6}{|l|}{ Relapse details } \\
\hline Relapse type & $\begin{array}{c}\text { Local relapse } \\
\text { Distant relapse } \\
\text { Combined }\end{array}$ & $\begin{array}{l}29 \\
65 \\
20\end{array}$ & $\begin{array}{l}37.9( \pm 9.0) \\
20.0( \pm 5.0) \\
13.3( \pm 8.1)\end{array}$ & $\begin{array}{c}34.5( \pm 8.8) \\
9.2( \pm 3.6) \\
\text { NR }\end{array}$ & .0189 \\
\hline Relapse site & $\begin{array}{c}\text { Local only } \\
\text { Lung } \pm \text { local } \\
\text { Extra-pulmonary }\end{array}$ & $\begin{array}{l}29 \\
40 \\
45\end{array}$ & $\begin{array}{r}37.9( \pm 9.0) \\
32.1( \pm 7.4) \\
6.7( \pm 3.7)\end{array}$ & $\begin{array}{r}34.5( \pm 8.8) \\
15.3( \pm 6.0) \\
2.2( \pm 2.2)\end{array}$ & $<.0001$ \\
\hline EFS1 & $\begin{array}{l}<18 \text { months } \\
\geq 18 \text { months }\end{array}$ & $\begin{array}{l}75 \\
39\end{array}$ & $\begin{array}{r}8.0( \pm 3.1) \\
53.4( \pm 8.1)\end{array}$ & $\begin{array}{r}6.7( \pm 2.9) \\
31.6( \pm 7.6)\end{array}$ & $<.0001$ \\
\hline Worst extent of disease & $\begin{array}{c}\text { Local } \\
\text { Lung } \\
\text { Extra-pulmonary }\end{array}$ & $\begin{array}{l}20 \\
40 \\
54\end{array}$ & $\begin{array}{c}40.0( \pm 11.0) \\
39.7( \pm 7.8) \\
5.6( \pm 3.1)\end{array}$ & $\begin{array}{c}35.0( \pm 10.7) \\
23.3( \pm 6.9) \\
1.9( \pm 1.8)\end{array}$ & $<.0001$ \\
\hline \multicolumn{6}{|l|}{ Relapse treatment } \\
\hline Chemotherapy or HDT & $\begin{array}{c}\text { HDT } \\
\text { Chemotherapy } \\
\text { None/palliative }\end{array}$ & $\begin{array}{l}29 \\
48 \\
37\end{array}$ & $\begin{array}{r}61.7( \pm 9.1) \\
16.7( \pm 5.4) \\
2.7( \pm 2.7)\end{array}$ & $\begin{array}{c}50.6( \pm 9.5) \\
4.2( \pm 2.9) \\
\text { NR }\end{array}$ & $<.0001$ \\
\hline Surgery and/or RT & $\begin{array}{l}\text { Yes } \\
\text { No }\end{array}$ & $\begin{array}{l}29 \\
85\end{array}$ & $\begin{array}{l}51.1( \pm 9.4) \\
14.1( \pm 3.8)\end{array}$ & $\begin{array}{r}39.6( \pm 9.3) \\
7.1( \pm 2.8)\end{array}$ & $<.0001$ \\
\hline
\end{tabular}

*2 patients with multifocal tumours are excluded from this comparison.

\section{Factors influencing survival}

Table 3 lists the PRS according to age, gender, primary site, metastases at diagnosis, relapse details, and treatment at relapse.

\section{Factors at diagnosis}

No influence on PRS was evident for gender, age at diagnosis, age at relapse, primary site, or tumour volume (Table 3).
When grouped together, patients with metastases at diagnosis had a poorer PRS compared to those with no metastases, but this was largely accounted for by the poor survival of 24 patients with extra-pulmonary metastases at diagnosis (Table 3).

\section{Factors at relapse}

Patients with local recurrence or lung metastases at relapse (with or without local recurrence) had superior survival 
TABLE 4: Summary of multivariate analysis.

\begin{tabular}{l|ccc}
\hline \multirow{2}{*}{ Variable $^{1}$} & \multicolumn{3}{c}{ Postrelapse survival } \\
\cline { 2 - 4 } & Parameter estimate & $P$ (chi-sq) & Hazard ratio \\
\hline $\begin{array}{l}\text { EFS1 } \geq 18 \text { months } \\
\text { Disease confined to local/lung at both } \\
\text { diagnosis and relapse }\end{array}$ & -1.007 & $<0.001$ & 0.365 \\
$\begin{array}{l}\text { Surgery and/or radical RT to site of } \\
\text { recurrence }\end{array}$ & -1.085 & $<0.001$ & 0.338 \\
HDT & -0.657 & 0.019 & $0.22-0.52$ \\
\hline
\end{tabular}

${ }^{1}$ Reference: relapse within 18 months, extra-pulmonary disease at diagnosis and/or relapse, no definitive local therapy at relapse, no HDT at relapse.

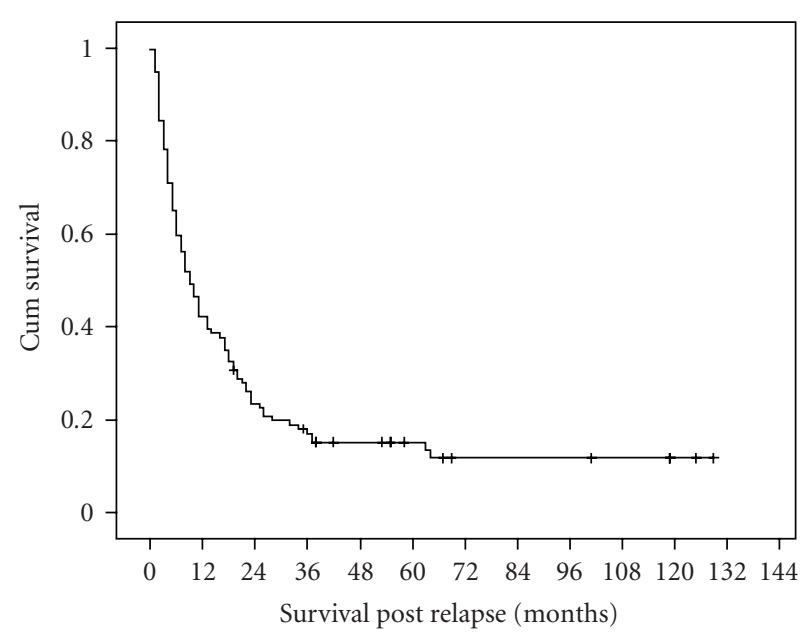

Figure 1: Postrelapse survival according to all patients $(n=114)$.

compared to those with extra-pulmonary recurrence. Moreover, patients with disease confined locally or to the lungs at both diagnosis and relapse had superior survival to those with extra-pulmonary disease at any time. Relapse within the first 18 months was also associated with inferior survival (Table 3).

\section{Treatment at relapse}

Whether patients received HDT or not at relapse was the strongest predictor of survival in univariate analysis, with a 5 -year PRS of $50.6 \%( \pm 9.5 \%)$ for those who received HDT compared to $3.5 \%( \pm 2.0 \%)$ for those who did not $(P<.001$; Figure 2). The ability to perform definitive local treatment to the site of relapse was also a strong predictor of outcome, with no difference seen between those who received surgery or those who received radiotherapy (Table 3 ).

\section{Multivariate analysis}

When considered in multivariate analysis, the strongest factors associated with superior survival were disease confined either to the primary site or to the lungs at both diagnosis and relapse; relapse greater than 18 months from diagnosis;

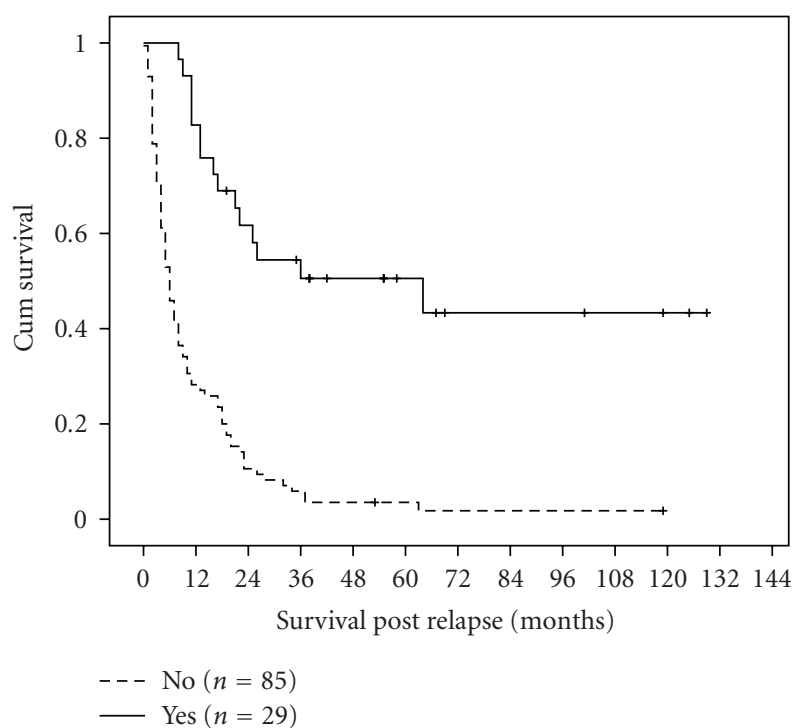

Figure 2: Postrelapse survival according to high-dose therapy (HDT) at relapse $(P<.001)$.

HDT at relapse; and definitive treatment to the site of relapse (Table 4).

\section{DISCUSSION}

This report describes the outcome of a large series of patients with ESFT after failure of first-line treatment. Although this is a retrospective analysis, the data presented is especially valuable as it reflects relatively recent practice in this disease, as this large number of patients has all been treated within a 10-year period. Although the outcome for the group overall is poor, there are a notable number of long-term survivors, and important and consistent factors associated with improved survival have been identified.

The 5-year PRS survival of $15.2 \%$ in this group of patients is in accordance with that described elsewhere. Reports detailing studies of first-line treatment describe a PRS between 0 and 22\% [11-18], although many of these studies includeonly patients with localised disease at diagnosis 
TABLE 5: Outcome of patients with relapsed Ewing's tumours, derived from reports of prospective clinical trials of first-line therapy. (Abbreviations: $\mathrm{AAW}=$ alive and well; $\mathrm{AWD}=$ alive with disease; $\mathrm{DR}=$ distant recurrence; $\mathrm{FU}=$ followup; $\mathrm{LR}=$ local recurrence; $\mathrm{PRS}=$ postrelapse survival; $\mathrm{PR}=$ postrelapse.)

\begin{tabular}{|c|c|c|c|c|c|}
\hline $\begin{array}{l}\text { Study, } \\
\text { period of study, } \\
\text { author }\end{array}$ & $\begin{array}{l}\text { Patients at } \\
\text { diagnosis }\end{array}$ & $\begin{array}{l}\text { Median FU } \\
\text { years (range) }\end{array}$ & $\begin{array}{l}\text { Relapsed } \\
\text { patients }\end{array}$ & $\begin{array}{l}\text { Outcome after } \\
\text { relapse }\end{array}$ & Notes \\
\hline $\begin{array}{l}\text { Bacci et al [11] } \\
1979-1995\end{array}$ & $\begin{array}{c}359 \\
\text { Localised }\end{array}$ & $\begin{array}{c}10.5 \\
(3.5-19)\end{array}$ & $\begin{array}{c}150 \\
\mathrm{LR}=1 \\
\mathrm{DR}=108 \\
\text { Both }^{(\mathrm{a})}=41\end{array}$ & $\begin{array}{l}\text { Overall: } \\
8 \text { AAW; } 6 \text { AWD }\end{array}$ & - \\
\hline $\begin{array}{l}\text { ET-1 } \\
1978-1986 \\
\text { Craft et al [12] }\end{array}$ & $\begin{array}{c}142 \\
120 \text { localised } \\
22 \text { metastatic }\end{array}$ & $\begin{array}{c}11.2 \\
(4.7-12)\end{array}$ & $\begin{array}{c}88 \\
\mathrm{LR}=26 \\
\mathrm{DR}=52 \\
\text { Both }=10\end{array}$ & $\begin{array}{l}\text { Only } 2 \text { of } 76 \text { with } \\
\text { metastatic relapse AAW }\end{array}$ & - \\
\hline $\begin{array}{l}\text { CESS } 86 \\
\text { 1986-1991 } \\
\text { Paulussen et al [13] }\end{array}$ & $\begin{array}{c}407 \\
\text { localised }\end{array}$ & $\begin{array}{c}6.4 \\
(0.2-13)\end{array}$ & $\begin{array}{c}125 \\
\mathrm{LR}=22 \\
\mathrm{DR}=92 \\
\text { Both }=11\end{array}$ & $\begin{array}{l}\text { 5-year PRS } \\
\text { LR: } 22 \%(4-41 \%) \\
\text { DR: } 11 \%(4-17 \%) \\
\text { Both: } 9 \%(0-26 \%)\end{array}$ & $\begin{array}{l}\text { - Relapse }>2 \text { years prognosis } \\
(P=.0015) \text { better } 5 \text { year PRS: } \\
18 \% \text { versus } 10 \% \\
\text { - Type of relapse not significant } \\
(P=.3095)\end{array}$ \\
\hline $\begin{array}{l}\text { NCI-86C169 } \\
1986-1992 \\
\text { Wexler et al [14] }\end{array}$ & $\begin{array}{l}\quad 54 \\
\text { localised } 31 \\
\text { metastatic } 23\end{array}$ & $\begin{array}{c}6.8 \\
(\min 3)\end{array}$ & $\begin{array}{c}27 \\
\mathrm{LR}=4 \\
\mathrm{DR}=17 \\
\text { Both }=6\end{array}$ & All died & - \\
\hline $\begin{array}{l}\text { ET2 } \\
1987-1993 \\
\text { Shankar et al [15] }\end{array}$ & $\begin{array}{c}191 \\
\text { Localised }\end{array}$ & $\begin{array}{c}5.5 \\
(0.2-10)\end{array}$ & $\begin{array}{c}61 \\
\mathrm{LR}=10 \\
\mathrm{DR}=43 \\
\text { Both }=8\end{array}$ & 11 alive $^{(\mathrm{b})}$ & $\begin{array}{l}\text { - Relapse }>2 \text { years better } \\
\text { prognosis }(P=.001) \\
\text { - Relapse site: not } \\
\text { significant }(P=.1)\end{array}$ \\
\hline $\begin{array}{l}\text { Bacci et al [16] } \\
1979-1996\end{array}$ & $\begin{array}{l}77 \\
\text { Local-pelvis }\end{array}$ & $\begin{array}{c}11 \\
(5-23)\end{array}$ & $\begin{array}{c}43 \\
\mathrm{LR}=6 \\
\mathrm{DR}=24 \\
\text { Both }=13\end{array}$ & $\begin{array}{l}42 \text { died: } 6-128 \text { months } \\
\text { PR } 1 \text { AAW, } 12 \text { years PR }\end{array}$ & - \\
\hline
\end{tabular}

(a) Defined by these authors as any patient who has ever experienced both a local recurrence and distant recurrence, regardless of the interval between them.

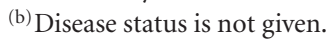

(Table 5). Time to first relapse has commonly been found to be a significant factor in influencing PRS, with those who relapse within 2 years of diagnosis having an inferior survival compared to those who relapse beyond 2 years [1$3,15,17,19,20]$. In this study we found that a cutoff of 18 months was a stronger predictor of survival, those relapsing after 18 months having an estimated 5-year PRS of $32 \%$. When disease progression occurs during first-line treatment subsequent survival is rarely reported. However 3 of 37 patients described in this study are long-term survivors, indicating that long-term remissions can occasionally be obtained with intensive treatments in selected patients with early progression.

Only a small number of studies have specifically examined survival after relapse in ESFT (Table 6). From these studies, factors associated with superior survival included relapse (rather than progression within first-line treatment) [21]; local recurrence only [1]; lung metastases rather than extra-pulmonary disease $[1,3]$; definitive surgery and/or radiotherapy to the site of relapse $[1,3]$; response to secondline therapy [22]; HDT at relapse [22]; and relapse more than 2 years from diagnosis $[1-3,20,22]$. Where stated, 5year PRS from these studies ranged from $13.8 \%$ to $20.0 \%$, (Table 6).

The survival of the cohort reported here compares favourably with these series, as the analysis was not confined to those with just localised disease at diagnosis and all had been treated with modern first-line regimens. A key goal in analysing and reporting this series was to identify treatment factors that might improve survival after relapse of ESFT. The results indicate the importance of an aggressive approach to local failure and, in particular, suggest a role for HDT in 
TABLE 6: Specific studies on the outcome of patients with relapsed Ewing's tumours. (Abbreviations: CHRMC = Children's Hospital and Regional Medical Center; AAW = alive and well; AWD = alive with disease; DR = distant recurrence; FLT = first-line treatment; FU = followup; LR = local recurrence; NS = not specified; Post $\mathrm{Tr}=$ posttreatment; PRS = postrelapse survival; LBSTS = London Bone and Soft Tissue Service; $2 \mathrm{LT}$ = second- line treatment.)

\begin{tabular}{|c|c|c|c|c|c|}
\hline $\begin{array}{l}\text { Study, } \\
\text { period of study, } \\
\text { author }\end{array}$ & $\begin{array}{l}\text { Patients at } \\
\text { diagnosis }\end{array}$ & $\begin{array}{l}\text { Median FU } \\
\text { years (range) }\end{array}$ & $\begin{array}{l}\text { Relapsed } \\
\text { patients }\end{array}$ & $\begin{array}{l}\text { Outcome after } \\
\text { relapse }\end{array}$ & $\begin{array}{l}\text { Factors associated with } \\
\text { improved outcome }\end{array}$ \\
\hline $\begin{array}{l}\text { St Judes } \\
1964-1980^{(a)} \\
\text { Hayes et al [21] }\end{array}$ & $\begin{array}{c}78 \\
\text { localised }\end{array}$ & NS & $\begin{array}{c}56 \\
22 \text { in FLT } \\
34 \text { Post Tr. }\end{array}$ & $\begin{array}{l}\rightarrow \text { All died } \\
\rightarrow 16 \text { AAW, } 2 \text { AWD }\end{array}$ & -NS \\
\hline $\begin{array}{l}\text { Eicess Database } \\
1981-1990 \\
\text { Paulessen et al [20] } \\
\text { (Abstract) }\end{array}$ & $\begin{array}{c}272 \\
\text { localised }\end{array}$ & 7 & 104 & $\begin{array}{c}89 \text { died } \\
\text { 10-year PRS: } 10 \%\end{array}$ & $\begin{array}{l}\text { - Relapse > } 2 \text { years } \\
\text { (10-year PRS: } \\
0 \% \text { versus 33\%) }\end{array}$ \\
\hline $\begin{array}{l}\text { St Judes } \\
1979-1999 \\
\text { Rodriguez- } \\
\text { Galindo } \\
\text { et al [1] }\end{array}$ & $\begin{array}{l}\text { (Relapsed only) } \\
41 \text { localised } \\
30 \text { metastasic }\end{array}$ & NS & $\begin{array}{c}71 \\
\mathrm{LR}=25 \\
\mathrm{DR}=34 \\
\text { Both }=12\end{array}$ & $\begin{array}{l}\text { 5-year PRS: (overall 17.7\%) } \\
\text { LR: } 22 \%( \pm 8 \%, \text { SE }) \\
\text { DR: } 18 \%( \pm 7 \%) \\
\text { Both } 13 \%( \pm 8 \%)\end{array}$ & $\begin{array}{l}\text { - Relapse > } 2 \text { years } \\
\text { - LR only } \\
\text { - Surgery for LR } \\
\text { - DR = lung only } \\
\text { - Lung irradiation }\end{array}$ \\
\hline $\begin{array}{l}\text { ET-2 } \\
\text { 1985-1996 } \\
\text { Shankar et al [2] }\end{array}$ & $\begin{array}{c}191 \\
\text { localised }\end{array}$ & NS & $\begin{array}{c}64 \\
\text { LR }=11 \\
\text { DR }=42 \\
\text { Both }=11\end{array}$ & $\begin{array}{l}\frac{\text { Overall: }}{3 \text { AAW; } 4 \text { AWD }} \\
55 \text { died }^{(b)} \\
2 \text { lost to FU }\end{array}$ & $\begin{array}{l}- \text { Relapse }>2 \\
\text { years }\end{array}$ \\
\hline $\begin{array}{l}\text { Rizzoli } \\
\text { 1979-1997 } \\
\text { Bacci et al [3] }\end{array}$ & $\begin{array}{c}429 \\
\text { localised }\end{array}$ & NS & $\begin{array}{c}195 \\
\mathrm{LR}=1 \\
\mathrm{DR}=138 \\
\text { Both }^{(\mathrm{c})}=56\end{array}$ & 5-year PRS: $13.8 \%$ & $\begin{array}{l}\text { - Relapse }>2 \text { years } \\
\text { - Surgery or RT at } \\
\text { relapse } \\
- \text { DR = lung only }\end{array}$ \\
\hline $\begin{array}{l}\text { CHRMC, Seattle } \\
\text { 1985-2002 } \\
\text { Barker et al [22] }\end{array}$ & $\begin{array}{l}\text { (Relapsed only) } \\
30 \text { localised } \\
25 \text { metastasic }\end{array}$ & NS & $\begin{array}{c}55 \\
\mathrm{LR}=6 \\
\mathrm{DR}=39 \\
\text { Both }=10\end{array}$ & $\begin{array}{c}\text { 5-year PRS: (overall 20\%) } \\
\text { LR: 50\% (95\% CI, 9-91) } \\
\text { DR: 20\% (95\% CI, 7-33) } \\
\text { Both: } 0\end{array}$ & $\begin{array}{l}\text { - Relapse > } 2 \text { years } \\
\text { - Response to 2LT } \\
\text { - HDT at relapse }\end{array}$ \\
\hline $\begin{array}{l}\text { LBSTS (this report) } \\
\text { 1992-2002 }\end{array}$ & $\begin{array}{l}\text { (Relapsed only) } \\
61 \text { localised } \\
53 \text { metastatic }\end{array}$ & $\begin{array}{c}5.6 \\
(1.1-10.8)\end{array}$ & $\begin{array}{c}114 \\
\text { LR }=29 \\
\text { DR }=65 \\
\text { Both }=20\end{array}$ & $\begin{array}{c}\text { 5-year PRS: (overall 15.2\%) } \\
\text { LR: } 35 \%( \pm 9 \%) \\
\text { DR: } 9 \%( \pm 4 \%) \\
\text { Both: } 0 \%\end{array}$ & $\begin{array}{l}\text { - Relapse > } 18 \text { months } \\
\text { - Local or lung disease only } \\
\text { - Surgery or RT at relapse } \\
\text { - HDT at relapse }\end{array}$ \\
\hline
\end{tabular}

\footnotetext{
(a) Includes 3 patients who had no chemotherapy during first-line treatment.

(b) 1 patient died in a road traffic accident, apparently disease free.

${ }^{(c)}$ Defined by these authors as any patient who has ever experienced both a local recurrence and distant recurrence, regardless of the interval between them.
}

improving PRS, previous evidence for which has principally been derived from registry reports $[23,24]$.

In this study, benefit of intensive treatment was confined to those with either local disease or lung metastases. It is therefore possible that a benefit similar to that reported for HDT might have been achieved had lung irradiation been used instead. This however seems unlikely as other evidence indicates only a small effect from the use of lung irradiation [25] and also when second-line treatment for ESFT fails, disease rarely remains confined to the lungs.
A limitation of all these studies is that as retrospective analyses it is not possible to control for selection bias. In both this series and that conducted by Barker et al [22], it is probable that some of the long-term survivors may have achieved the same status without the use of HDT. However it is unlikely that this would be the case for all the survivors in the series reported here. In the absence of evidence from prospective randomised studies of HDT in patients with relapsed ESFT, which would present insuperable challenges to conduct, consolidation of response with HDT would appear 
to be an appropriate goal where possible, given the otherwise uniformly dismal outlook for patients with relapsed disease.

\section{REFERENCES}

[1] Rodriguez-Galindo C, Billups CA, Kun LE, et al. Survival after recurrence of Ewing tumors: the St. Jude children's research hospital experience, 1979-1999. Cancer. 2002;94(2):561-569.

[2] Shankar AG, Ashley S, Craft AW, Pinkerton CR. Outcome after relapse in an unselected cohort of children and adolescents with Ewing sarcoma. Medical and Pediatric Oncology. 2003;40(3):141-147.

[3] Bacci G, Ferrari S, Longhi A, et al. Therapy and survival after recurrence of Ewing's tumors: the Rizzoli experience in 195 patients treated with adjuvant and neoadjuvant chemotherapy from 1979 to 1997. Annals of Oncology. 2003;14(11):16541659.

[4] Craft A, Cotterill S, Malcolm A, et al. Ifosfamide-containing chemotherapy in Ewing's sarcoma: the second United Kingdom Children's Cancer Study Group and the Medical Research Council Ewing's Tumor Study. Journal of Clinical Oncology. 1998;16(11):3628-3633.

[5] Paulussen M, Craft A, Lewis I. Ewing tumor of bone-updated report of the European Intergroup Cooperative Ewing's Sarcoma Study EICESS 92. Proceedings of the American Society of Clinical Oncology. 2002;21(abstract):1568.

[6] Strauss SJ, McTiernan A, Driver D, et al. Single center experience of a new intensive induction therapy for Ewing's family of tumors: feasibility, toxicity, and stem cell mobilization properties. Journal of Clinical Oncology. 2003;21(15):2974-2981.

[7] Kaplan EL, Meier P. Nonparametric estimation from incomplete observations. Journal of the American Statistical Association. 1958;53(282):457-481.

[8] Cox DR, Oakes D. Analysis of Survival Data. London, UK: Chapman and Hall; 1984.

[9] Whelan JS, McTiernan A, Kakouri E, Kilby A. Carboplatinbased chemotherapy for refractory and recurrent Ewing's tumours. Pediatric Blood and Cancer. 2004;43(3):237-242.

[10] Seddon BM, McTiernan A, Michelagnoli M, Gabbie S, Daw $S$, Whelan JS. High-dose ifosfamide in relapsed or progressive Ewing's sarcoma. Sarcoma. 2005;9(abstract):108.

[11] Bacci G, Ferrari S, Bertoni F, et al. Prognostic factors in nonmetastatic Ewing's sarcoma of bone treated with adjuvant chemotherapy: analysis of 359 patients at the Istituto Ortopedico Rizzoli. Journal of Clinical Oncology. 2000;18(1):4-11.

[12] Craft AW, Cotterill SJ, Bullimore JA, Pearson D. Long-term results from the first UKCCSG Ewing's tumour study (ET-1). United Kingdom Children's Cancer Study Group (UKCCSG) and the Medical Research Council Bone Sarcoma Working Party. European Journal of Cancer. 1997;33(7):1061-1069.

[13] Paulussen M, Ahrens S, Dunst J, et al. Localized Ewing tumor of bone: final results of the Cooperative Ewing's Sarcoma Study CESS 86. Journal of Clinical Oncology. 2001;19(6):18181829.

[14] Wexler LH, DeLaney TF, Tsokos $M$, et al. Ifosfamide and etoposide plus vincristine, doxorubicin, and cyclophosphamide for newly diagnosed Ewing's sarcoma family of tumors. Cancer. 1996;78(4):901-911.

[15] Shankar AG, Pinkerton CR, Atra A, et al. Local therapy and other factors influencing site of relapse in patients with localised Ewing's sarcoma. United Kingdom Children's Cancer Study Group (UKCCSG). European Journal of Cancer. 1999;35(12):1698-1704.
[16] Bacci G, Ferrari S, Mercuri M, et al. Multimodal therapy for the treatment of nonmetastatic Ewing sarcoma of pelvis. Journal of Pediatric Hematology/Oncology. 2003;25(2):118-124.

[17] Bacci G, Picci P, Ferrari S, et al. Neoadjuvant chemotherapy for Ewing's sarcoma of bone: no benefit observed after adding ifosfamide and etoposide to vincristine, actinomycin, cyclophosphamide, and doxorubicin in the maintenance phase-results of two sequential studies. Cancer. 1998;82(6):1174-1183.

[18] Bacci G, Mercuri M, Longhi A, et al. Neoadjuvant chemotherapy for Ewing's tumour of bone: recent experience at the Rizzoli Orthopaedic Institute. European Journal of Cancer. 2002;38(17):2243-2251.

[19] Cotterill SJ, Ahrens S, Paulussen M, et al. Prognostic factors in Ewing's tumor of bone: analysis of 975 patients from the European Intergroup Cooperative Ewing's Sarcoma Study Group. Journal of Clinical Oncology. 2000;18(17):3108-3114.

[20] Paulussen M, Ahrens S, Braun-Munzinger G, et al. Survival in primary disseminated or relapsed Ewing's tumorEICESS/CESS data. Medical and Pediatric Oncology. 1996; 27(abstract):237.

[21] Hayes FA, Thompson EI, Kumar M, Hustu HO. Longterm survival in patients with Ewing's sarcoma relapsing after completing therapy. Medical and Pediatric Oncology. 1987;15(5):254-256.

[22] Barker LM, Pendergrass TW, Sanders JE, Hawkins DS. Survival after recurrence of Ewing's sarcoma family of tumors. Journal of Clinical Oncology. 2005;23(19):4354-4362.

[23] Ladenstein R, Lasset C, Pinkerton R, et al. Impact of megatherapy in children with high-risk Ewing's tumours in complete remission: a report from the EBMT Solid Tumour Registry. Bone Marrow Transplantation. 1995;15(5):697-705.

[24] Frohlich B, Ahrens S, Burdach S, et al. High-dosage chemotherapy in primary metastasized and relapsed Ewing's sarcoma. (EI)CESS. Klinische Pädiatrie. 1999;211(4):284-290.

[25] Whelan JS, Burcombe RJ, Janinis J, Baldelli AM, Cassoni AM. A systematic review of the role of pulmonary irradiation in the management of primary bone tumours. Annals of Oncology. 2002;13(1):23-30. 


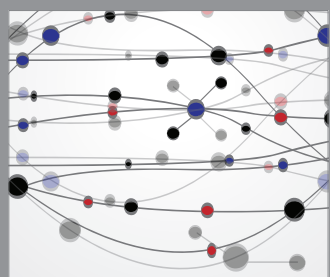

The Scientific World Journal
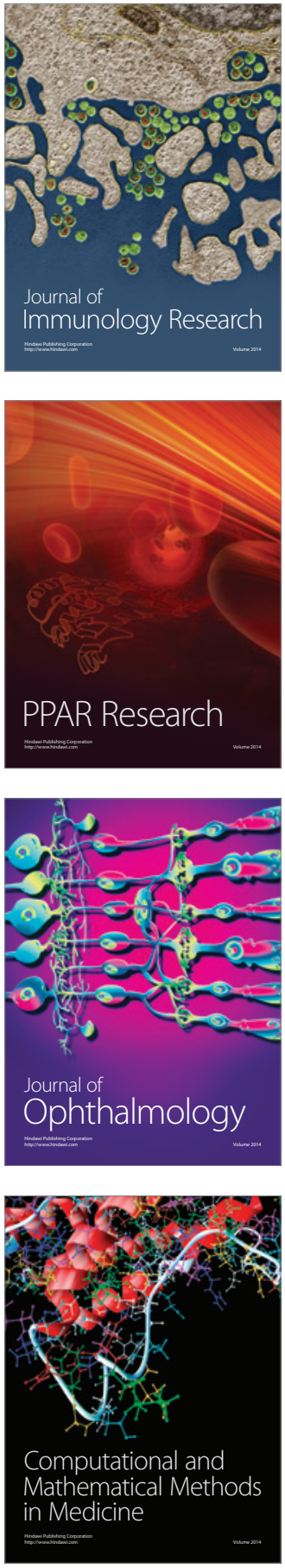

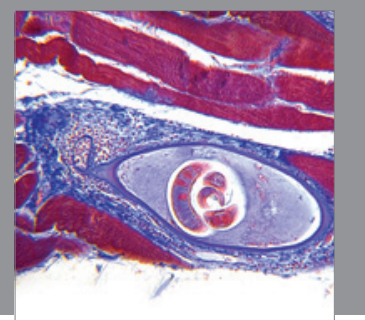

Gastroenterology

Research and Practice
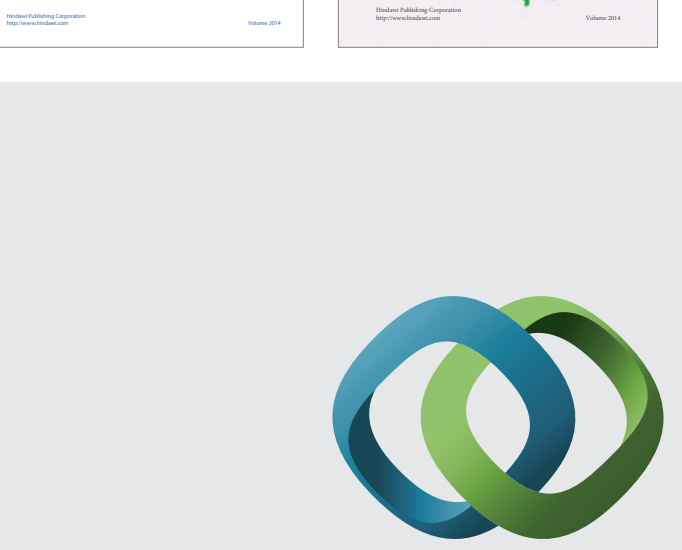

\section{Hindawi}

Submit your manuscripts at

http://www.hindawi.com
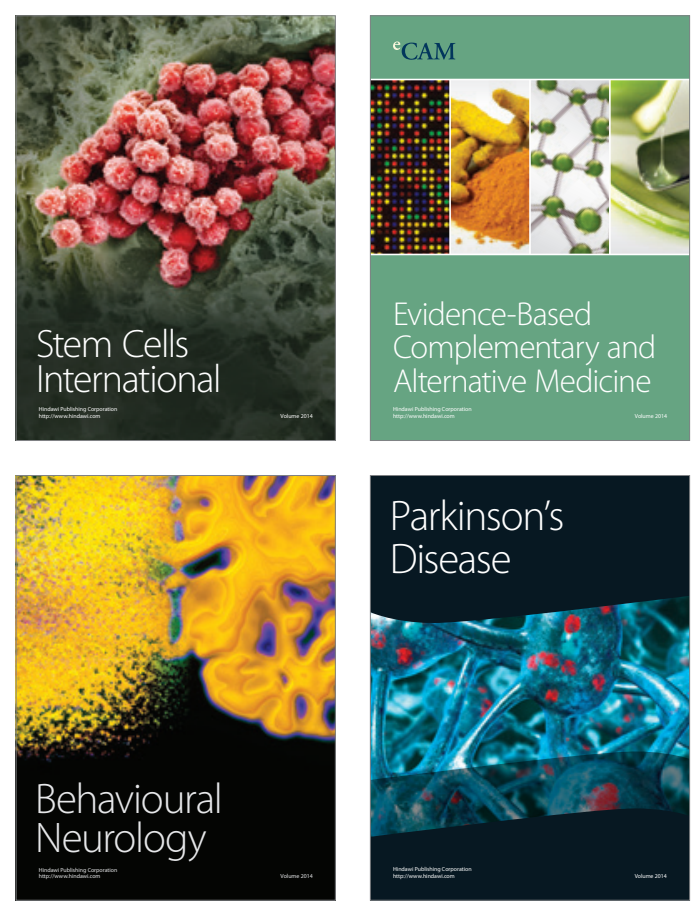

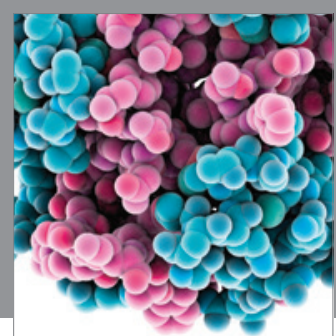

Journal of
Diabetes Research

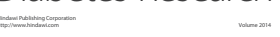

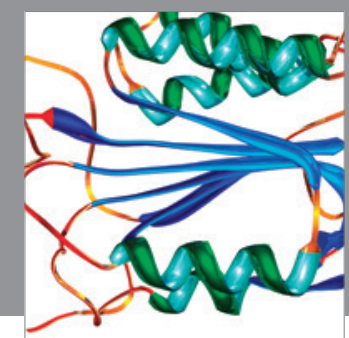

Disease Markers
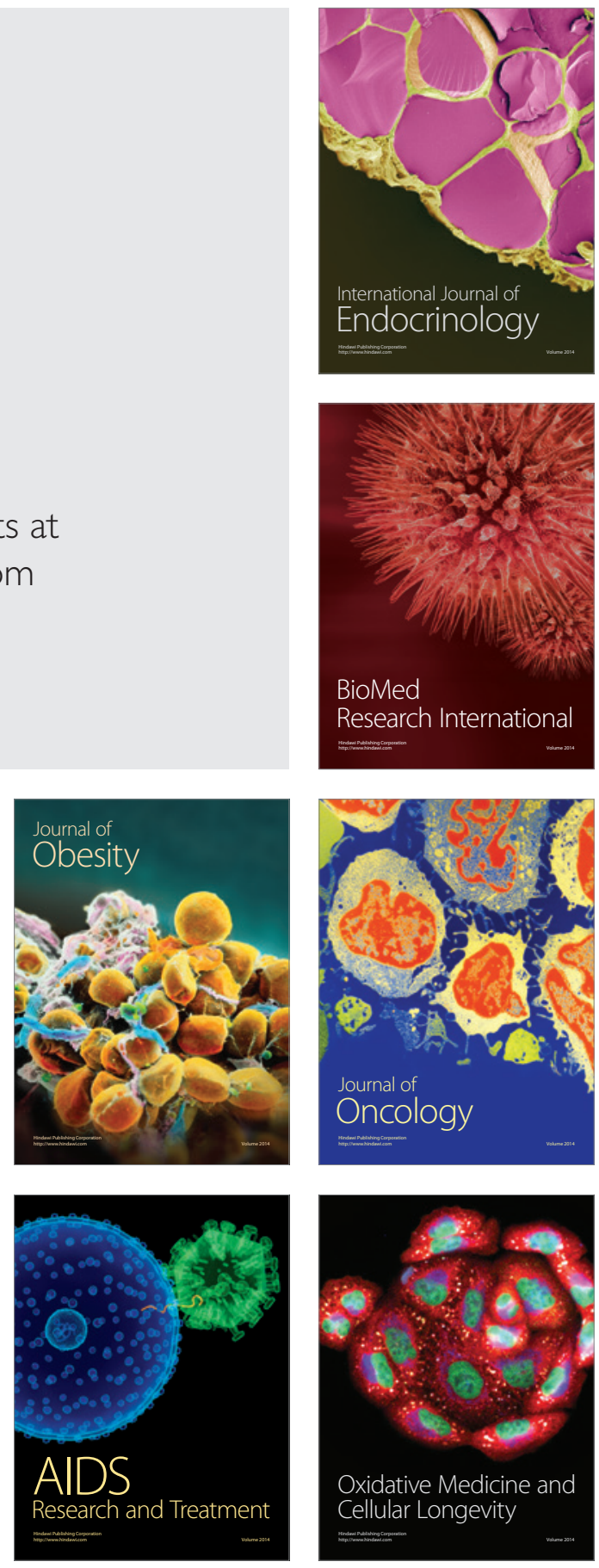